\title{
Penerapan Model Pembelajaran Kooperatif Tipe MURDER (Mood, Understand, Recall, Degest, Expand, Review) Untuk Meningkatkan Hasil Belajar Fisika Siswa Kelas VIII SMP Negeri 16 Palu
}

\author{
Muliawati Ayunani \\ Email: ayoe_mean@yahoo.com \\ Prodi Pendidikan Fisika, Jurusan Pendidikan MIPA, Universitas Tadulako \\ Jl. Soekarno Hatta KM. 9 Kampus Bumi Tadulako Tondo Palu - Sulawesi Tengah
}

\begin{abstract}
Abstrak - Penelitan tindakan kelas ini bertujuan untuk meningkatkan hasil belajar fisika siswa kelas VIIIC SMP Negeri 16 Palu. Masalah yang diteliti adalah rendahnya hasil belajar siswa pada mata pelajaran IPA Fisika SMP. Subyek penelitian berjumlah 34 orang siswa kelas VIIIC SMP Negeri 16 Palu. Jenis Penelitian Tindakan Kelas yang dilaksanakan secara bersiklus, untuk tiap siklus ada 4 tahap: (i) perencanaan (ii) pelaksanaan tindakan (iii) observasi (iv) refleksi. Jenis data yang diperoleh adalah data kualitatif dan data kuantitatif. Data kualitatif merupakan data yang diperoleh dalam kegiatan belajar mengajar berupa observasi dan wawancara. Sedangkan data kuantitatif merupakan data hasil belajar yang diperoleh dengan tes. Hasil penelitian pada siklus I, observasi aktivitas guru berada pada kategori baik dengan rata-rata persentase sebesar $80,6 \%$ dan aktivitas siswa berada pada kategori cukup dengan rata-rata persentase sebesar 76,4\%. Hasil penelitian pada siklus II, observasi aktivitas guru berada pada kategori sangat baik dengan rata-rata persentase sebesar $91,7 \%$ dan aktivitas siswa berada pada kategori sangat baik dengan rata-rata persentase sebesar 90,3\%. Hasil wawancara siklus I dan II menunjukkan bahwa siswa senang dengan penerapan model pembelajaran kooperatif tipe MURDER. Hasil belajar siklus I diperoleh kentutasan belajar klasikal yakni $61,8 \%$ dengan jumlah yang tuntas sebanyak 21 orang siswa dan yang belum tuntas 13 orang siswa. Pada siklus II ketuntasan belajar klasikal sebanyak $82,4 \%$ dengan rincian 28 orang siswa tuntas dan 6 orang siswa yang masih belum tuntas. Berdasarkan hasil tersebut dapat disimpulkan bahwa dengan penerapan model pembelajaran kooperatif tipe MURDER dapat meningkatkan hasil belajar fisika siswa kelas VIIIC SMP Negeri 16 Palu.
\end{abstract}

Kata Kunci: Pembelajaran Kooperatif, MURDER, Hasil Belajar Fisika

\section{PENDAHULUAN}

Pendidikan memegang peranan penting dalam pengembangan sumber daya manusia yang lebih bermutu. Untuk melaksanakan peran pendidikan tersebut pemerintah khususnya Departemen Pendidikan Nasional berupaya meningkatkan mutu pendidikan di Indonesia. Usaha tersebut dapat dilihat dengan diadakannya pembaharuan kurikulum, pengembangan metode mengajar, peningkatan kualitas dan kuantitas tenaga pengajar, pengadaan peralatan yang dapat menunjang pengajaran dan sistem administrasi yang lebih teratur. Pendidikan sekolah merupakan amanah untuk mengembangkan sumber daya manusia yang dilakukan secara sistematis, praktis dan berjenjang.

Berdasarkan hasil observasi dengan mewawancarai salah satu guru fisika di SMP Negeri 16 Palu, diperoleh informasi bahwa sebagian besar siswa kelas VIII masih mengalami kesulitan dalam belajar. Hal ini disebabkan oleh model pembelajaran langsung yang diterapkan guru di SMP Negeri 16 Palu yang masih berpusat pada guru (teacher oriented). Pola pembelajaran seperti ini siswa hanya sebagai obyek dalam kegiatan belajar mengajar, dengan kata lain siswa kurang aktif dalam kegiatan belajar mengajar karena hanya berpusat pada guru, sehingga siswa tidak dapat mengembangkan ide serta menggali pengetahuannya sendiri, akibatnya siswa tidak dapat berpikir kreatif dalam menyelesaikan semua masalah. Hal ini sesuai dengan informasi dari salah seorang guru di SMP Negeri 16 Palu, yang mengatakan bahwa sebagian besar siswa mengalami kesulitan belajar, khususnya mata pelajaran fisika. Banyak siswa yang beranggapan bahwa fisika itu sulit, siswa juga tidak mengetahui manfaat belajar fisika dalam kehidupan sehari-hari, sehingga hasil tersebut akan berdampak pada hasil belajar fisika siswa kelas VIII dengan standar kriteria ketuntasan minimal yang ditetapkan sekolah harus dicapai 75,0 . Hal tersebut dapat dilihat pada tabel nilai rata-rata hasil belajar siswa yang diperoleh dari Guru Fisika kelas VIII SMP Negeri 16 Palu Tahun Ajaran 2011-2012. 
TABEL 1. Hasil Belajar Fisika Siswa Tahun Ajaran 2011-2012

\begin{tabular}{|c|c|c|}
\hline No. & Kelas & Nilai rata-rata \\
\hline 1. & VIIIA & 73,8 \\
\hline 2. & VIIIB & 75,4 \\
\hline 3. & VIIIC & 71,9 \\
\hline
\end{tabular}

(SUMBER : SMP NEGERI 16 PALU)

Pelaksanaan mengajar di sekolah, guru mempunyai peranan yang sangat besar demi tercapainya proses belajar yang baik. Sehubungan dengan peranan ini, seorang guru dituntut harus mempunyai kompetensi yang memadai dalam hal pengajaran di sekolah. Kurangnya kompetensi guru akan menyebabkan pelaksanaan mengajar menjadi kurang lancar yang mengakibatkan siswa tidak senang dalam pelajaran sehingga siswa dapat mengalami berbagai kesulitan belajar dan prestasi belajar menurun. Selain itu, guru juga harus memiliki kemampuan yang baik dalam penguasaan materi maupun dalam menggunakan pendekatan, model dan strategi pembelajaran yang member perhatian cukup pada pemahaman siswa terhadap konsep fisika. Pemahaman konsep dapat dibangun sendiri oleh siswa dengan memberikan kesempatan berperan lebih aktif dalam proses pembelajaran

Sehubungan dengan hal tersebut di atas, maka dalam penelitian ini penulis tertarik untuk mengkaji "Penerapan Model Pembelajaran Kooperatif MURDER (Mood, Understand, Recall, Digest, Expand, Review) Untuk Meningkatkan Hasil Belajar Fisika Siswa Kelas VIII SMP Negeri 16 Palu."

cooperative learning adalah suatu model pembelajaran dimana siswa belajar dan bekerja sama dalam kelompok-kelompok kecil secara kolaboratif yang anggotanya terdiri dari 4-6 orang dengan struktur kelompok yang bersifat heterogen. Ref. [1]

Ada lima unsur dasar dalam pembelajaran kooperatif (cooperative learning), yaitu sebagai (1) Prinsip ketergantungan positif (positive interdependence), (2) Tanggung jawab perseorangan (individual accountability), (3) Interaksi tatap muka (face to face promotion interaction), (4) Partisipasi dan komunikasi (participation communication), (5) Evaluasi proses kelompok. Ref. [2]

Pembelajaran MURDER merupakan pembelajaran yang diadaptasi dari buku karya Bob Nelson "The Complete Problem Solver" yang merupakan gabungan dari beberapa kata yang meliputi: (1) Mood (Suasana Hati), (2) Understand (Pemahaman), (3) Recall
(Pengulangan), (4) Digest (Penelaahan), (5) Expand (Pengembangan), (6) Review (Pelajari Kembali). Ref.[3]

Hasil belajar merupakan hal yang dapat dipandang dari dua sisi yaitu sisi siswa dan sisi guru. Dari sisi siswa, hasil belajar merupakan tingkat perkembangan mental yang lebih baik bila dibandingkan pada saat sebelum belajar. Tingkat perkembangan mental tersebut terwujud pada jenis-jenis ranah kognitif, afektif, dan psikomotor. Sedangkan dari sisi guru, hasil belajar meupakan saat terselesaikannya bahan pelajaran. Ref.[4]

\section{METODOLOGI PENELITIAN}

Penelitian ini dilaksanakan di SMP Negeri 16 Palu. Pelaksanaan tindakan ini dilaksanakan dalam siklus berulang yang terdiri dari dua siklus, untuk tiap siklus meliputi 4 tahap yaitu perencanaan, pelaksanaan tindakan, observasi, refleksi. Pengunaan model ini dikarenakan alur yang digunakan cukup sederhana dan mudah untuk dilaksanakan. Tahapan penelitian ini mengacu pada model Kurt Lewin yang dikembangkan oleh Kemmis dan Mc. Taggart. Ref.[5]

Subyek penelitian ini adalah siswa kelas VIIIC SMP Negeri 16 Palu yang mengikuti mata pelajaran fisika tahun ajaran 2011/2012 dengan jumlah siswa 34 orang siswa yang terdiri dari 14 orang siswa laki-laki dan 20 orang siswa perempuan, metode pengumpulan data pada penelitian ini, meliputi beberapa cara yaitu, observasi dan tes hasil belajar. Faktorfaktor yang diteliti dalam penelitian ini adalah aktivitas guru, aktivitas siswa, afektifitas individu dan kinerja kelompok, serta hasil belajar siswa. Analisa data terbagi menjadi dua kelompok yaitu analisa data kuantitatif dan data kualitatif. Ref.[6]

Hipotesis tindakan pada penelitian ini adalah dengan melalui penerapan model pembelajaran kooperatif MURDER (Mood, Understand, Recall, Digest, Expand, Review) dapat meningkatkan hasil belajar fisika siswa kelas VIII SMP Negeri 16 Palu.

\section{HASIL DAN PEMBAHASAN}

Pada tindakan siklus I dan siklus II dilaksanakan 6 kali pertemuan, untuk setiap siklus dilakukan dengan 3 kali pertemuan yang terdiri dari 2 kali pertemuan kegiatan belajar mengajar (KBM) dan 1 kali pertemuan untuk tes akhir tindakan. Pada pelaksanaan tindakan observasi terhadap aktivitas siswa dan guru 
(peneliti) dilakukan sebanyak 2 kali pada saat proses pembelajaran berlangsung.

Tabel 2. Observasi Aktivitas Siswa

\begin{tabular}{|c|c|c|c|c|}
\hline \multirow{2}{*}{ Pertemuan } & \multicolumn{2}{|c|}{ Siklus I } & \multicolumn{2}{c|}{ Siklus II } \\
\cline { 2 - 5 } & $\begin{array}{c}\text { Persen } \\
\text { tase }\end{array}$ & Kategori & $\begin{array}{c}\text { Persen } \\
\text { tase }\end{array}$ & Kategori \\
\hline $\begin{array}{c}\text { Pertama } \\
\text { (I) }\end{array}$ & $72,22 \%$ & Cukup & $88,88 \%$ & Baik \\
\hline $\begin{array}{c}\text { Kedua } \\
\text { (II) }\end{array}$ & $80,55 \%$ & Baik & $91,66 \%$ & $\begin{array}{c}\text { Sangat } \\
\text { Baik }\end{array}$ \\
\hline
\end{tabular}

Berdasarkan hasil observasi aktivitas siswa pada Tabel 2 menunjukkan bahwa siklus I persentase nilai rata-rata (NR) aktivitas siswa pada pertemuan pertama berada dalam kategori cukup dengan persentase $72,22 \%$ dan untuk pertemuan kedua berada dalam kategori baik dengan persentase $80,55 \%$, sedangkan pada siklus II menunjukkan bahwa persentase nilai rata-rata (NR) aktivitas siswa pada pertemuan pertama berada dalam kategori baik dengan persentase $88,88 \%$ dan untuk pertemuan kedua berada dalam kategori sangat baik dengan persentase 91,66, dan pada aktivitas guru dapat dilihat pada tabel 3 .

Tabel 3. Observasi Aktivitas Guru

\begin{tabular}{|c|c|c|c|c|}
\hline \multirow{2}{*}{ Pertemuan } & \multicolumn{2}{|c|}{ Siklus I } & \multicolumn{2}{c|}{ Siklus II } \\
\cline { 2 - 5 } & $\begin{array}{c}\text { Persen } \\
\text { tase }\end{array}$ & Kategori & $\begin{array}{c}\text { Persen } \\
\text { tase }\end{array}$ & Kategori \\
\hline $\begin{array}{c}\text { Pertama } \\
\text { (I) }\end{array}$ & $75 \%$ & Cukup & $88,89 \%$ & Baik \\
\hline $\begin{array}{c}\text { Kedua } \\
\text { (II) }\end{array}$ & $86,11 \%$ & Baik & $94,44 \%$ & $\begin{array}{c}\text { Sangat } \\
\text { Baik }\end{array}$ \\
\hline
\end{tabular}

Berdasarkan hasil observasi aktivitas guru pada Tabel 3 menunjukkan bahwa siklus II persentase nilai rata-rata (NR) aktivitas siswa pada pertemuan pertama berada dalam kategori cukup dengan persentase $75 \%$ dan untuk pertemuan kedua berada dalam kategori baik dengan persentase $86,11 \%$, sedangkan pada siklus II menunjukkan bahwa persentase nilai rata-rata (NR) aktivitas siswa pada pertemuan pertama berada dalam kategori baik dengan persentase $88,89 \%$ dan untuk pertemuan kedua berada dalam kategori sangat baik dengan persentase $94,44 \%$.

Hasil belajar siswa secara lengkap ditunjukkan oleh Tabel 4.

Tabel 4. Hasil Belajar Siswa Siklus I Dan Siklus II

\begin{tabular}{|c|l|c|c|}
\hline \multirow{2}{*}{ No. } & \multirow{2}{*}{ Aspek Perolehan } & \multicolumn{2}{|c|}{ Hasil } \\
\cline { 3 - 4 } & & Suklus I & Siklus II \\
\hline 1. & Skor tertinggi & 86,7 & 93,3 \\
\hline 2. & Skor terendah & 40,0 & 53,3 \\
\hline 3. & daya serap klasikal & $70,0 \%$ & $78,8 \%$ \\
\hline
\end{tabular}

ISSN 23383240

\begin{tabular}{|c|l|c|c|}
\hline 4. & ketuntasan belajar klasikal & $61,8 \%$ & $82,4 \%$ \\
\hline 5. & $\begin{array}{l}\text { Banyaknya siswa yang } \\
\text { tuntas }\end{array}$ & $\begin{array}{c}21 \\
\text { orang }\end{array}$ & $\begin{array}{c}28 \\
\text { orang }\end{array}$ \\
\hline 6. & $\begin{array}{l}\text { Banyaknya siswa yang tidak } \\
\text { tuntas }\end{array}$ & $\begin{array}{c}13 \\
\text { orang }\end{array}$ & $\begin{array}{c}6 \\
\text { orang }\end{array}$ \\
\hline
\end{tabular}

Dari hasil tes akhir tindakan siklus I memperlihatkan bahwa hasil belajar siswa masih kurang baik. Masih terdapat beberapa soal yang belum dapat diselesaikan dengan baik oleh siswa, sedangakan dari hasil tes akhir tindakan siklus II terlihat bahwa adanya peningkatan ketuntasan klasikal yang diperoleh siswa dibandingkan pada siklus sebelumnya, dan daya serap klasikal juga mengalami peningkatan dari siklus sebelumnya. Meskipun demikian, masih ada beberapa orang siswa yang tidak mampu menjawab soal dengan baik, terutama pada soal perhitungan. Namun secara klasikal sudah mencapai target indikator kinerja yaitu melebihi $75 \%$.

Rendahnya hasil belajar pada siklus I disebabkan karena siswa belum dapat memahami dengan baik model pembelajaran yang diterapkan sehingga diskusi kelompok waktu KBM berlangsung sebagian tidak mengerjakan dengan baik tugas yang diberikan, serta perhatian siswa yang kurang saat KBM berlangsung. Selain itu, faktor kemalasan menyebabkan rendahnya hasil belajar fisika siswa kelas VIIIc.

Dari hasil wawancara diketahui bahwa siswa senang dengan model pembelajaran yang diterapkan di kelas, karena menurut siswa mereka lebih santai serta tidak tegang saat KBM serta dapat bekerjasama dengan teman kelompok, meskipun pada pertemuan pertama siswa masih bingung dengan tugas kelompok yang diberikan serta siswa masih kurang memahami dengan baik materi yang disampaikan karena guru menyampaikan materi terlalu cepat sehingga ada siswa yang tidak dapat mendengarkan penyampaian guru dengan baik.

Pada tahap ini peneliti melaksanakan tes pratindakan atau tes awal pada siswa yang akan diteliti dan melakukan wawancara langsung terhadap guru mata pelajaran Fisika siswa kelas VIIIc SMP Negeri 16 Palu. Berdasarkan hasil dari tes awal yang diberikan pada siswa, diperoleh daya serap klasikal mencapai $53,1 \%$ dan ketuntasan belajar klasikal 29,4 \%. Dari hasil tersebut dapat dijelaskan bahwa sebelum penerapan model pembelajaran kooperatif tipe MURDER pada siswa belum mampu mencapai ketuntasan belajar dengan indikator $75 \%$ serta daya serap 
klasikal yaitu $75 \%$. Selain itu, terlihat masih banyak siswa yang belum tuntas yaitu sebanyak 24 orang. Hal ini disebabkan karena siswa masih kurang dilibatkan dalam proses pembelajaran sehingga siswa cenderung bermain-main dalam kelas serta tidak serius mengikuti proses belajar. Selain itu, siswa masih kesulitan dalam menjawab soal-soal serta dalam mengkonversi besaran dan satuan fisika. Guru juga kurang memberikan kegiatan yang bersifat nyata seperti penyampaian materi dengan melakukan demonstrasi alat

Pembentukan kelompok diambil dari hasil tes awal yang telah diberikan. Siswa dibagi dalam enam kelompok, dalam setiap kelompok terdiri dari 4 atau 6 orang siswa yang berkemampuan tinggi, sedang dan rendah.

Berdasarkan data hasil belajar dan observasi guru dan siswa selama kegiatan pembelajaran di tiap siklus, dapat disimpulkan bahwa aktivitas siswa selama mengikuti proses pembelajaran dari siklus I hingga siklus II mengalami peningkatan. Hal ini dapat dilihat dari grafik peningkatannya pada Gbr 1

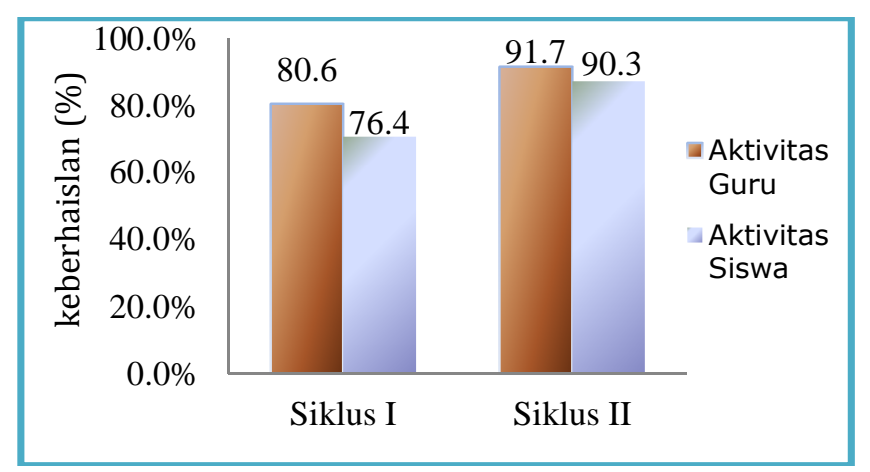

Gambar 1 Grafik Peningkatan Proses Pembelajaran

Pada siklus I, aktivitas siswa dan aktivitas guru untuk pertemuan 1 dan 2 berada pada kategori cukup dan baik. Pada siklus I ini, siswa belum bisa bekerjasama dengan baik bersama teman kelompoknya karena siswa belum terbiasa dengan model pembelajaran yang diterapkan oleh guru (peneliti). Selain itu, sebagian siswa masih terlihat belum siap mengikuti pembelajaran, dikarenakan beberapa siswa datang terlambat saat jam pelajaran dimulai dan masih sibuk dengan kegiatan masing-masing. Siswa juga kurang memberikan tanggapannya mengenai materi yang disampaikan hal ini dikarenakan siswa merasa malu dan ragu-ragu untuk bertanya maupun menjawab pertanyaan dari guru. Berdasarkan beberapa kondisi tersebut, Pada siklus II guru (peneliti) berusaha untuk tegas dalam meningkatkan kedisiplinan siswa yang sering terlambat masuk kelas, berusaha menciptakan
ISSN 23383240

suasana keakraban bersama siswa sehingga mereka tidak merasa takut dan malu untuk bertanya. Guru juga berusaha memotivasi siswa dalam mengungkapkan ide-ide mereka dan membangun kerjasama mereka melalui pembelajaran. Berdasarkan hasil wawancara setelah pelaksanaan tes hasil belajar siklus I, beberapa siswa masih merasa kurang paham dengan penyampaian materi yang disampaikan guru.

Dari gambar 1 terlihat jelas ada peningkatan hasil belajar dari siklus I ke siklus II, sehingga dapat dikatakan bahwa model pembelajaran MURDER dapat meningkatkan aktivitas siswa. Keaktifan siswa dalam kegiatan belajar mengajar (KBM) dari siklus I ke siklus II mengalami peningkatan. Peningkatan ini terjadi karena kekurangan-kekurangan pada siklus I dapat diminimalisir dengan melakukan perbaikan pada siklus II sesuai dengan rekomendasi pada siklus I. Dengan melakukan perbaikan, maka penilaian terhadap aktivitas siswa pada siklus II menjadi meningkat. Hal ini dapat dilihat pada persentase ketercapaiannya mencapai 90,3 \%. Siswa terlihat antusias dalam menyelesaikan setiap soal yang diberikan kepada mereka.

Selain peningkatan pada siswa secara individu, terjadi pula peningkatan pada aktivitas kelompok. Hal ini dapat dilihat dari hasil perolehan persen ketercapaian aktivitas kelompok yang mencapai $91,7 \%$ pada siklus II. Peningkatan tersebut dikarenakan guru (peneliti) berusaha untuk meminimalisir kekurangan-kekurangan yang terjadi pada siklus I dan melakukan perbaikan berdasarkan rekomendasi. Menjelaskan pada siswa bahwa dengan adanya kerja sama dan saling berinteraksi dalam kelompok menuntut siswa saling menghargai pendapat dan berdiskusi untuk menyelesaikan tugas yang diberikan oleh guru, sehingga siswa bisa lebih mudah menyelesaikan tugas yang diberikan oleh guru.

Berdasarkan hasil penelitian yang dilakukan, diketahui bahwa model pembelajaran yang digunakan merupakan salah satu alternatif untuk meningkatkan hasil belajar fisika. Hal ini dapat dilihat pada grafik nilai rata-rata hasil belajar siswa pada siklus I dan siklus II seperti pada Gbr 2. 


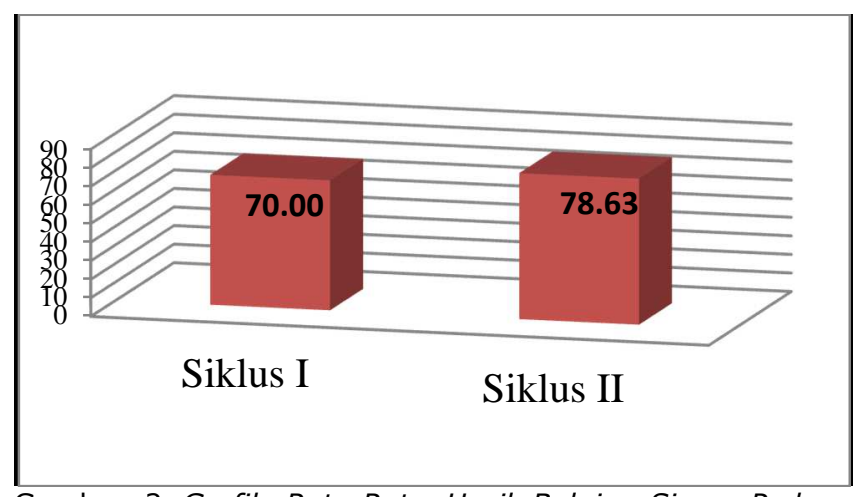

Gambar 2. Grafik Rata-Rata Hasil Belajar Siswa Pada Siklus I Dan Siklus II

Dalam mengerjakan tes pada setiap siklus, terlihat masih terdapat sejumlah siswa yang belum bisa mengerjakan tes dengan baik, khususnya dalam mengerjakan tes dalam bentuk pemahaman dan perhitungan. Beberapa siswa masih kurang paham dalam menggunakan rumus yang ada, walaupun telah diajarkan cara mudah dalam menggunakan rumus untuk menyelesaikan soal. Dari gambar 2 terlihat bahwa hasil yang diperoleh pada siklus II lebih baik dari siklus I. Peningkatan hasil yang signifikan dapat dilihat pada ketuntasan belajar klasikal yang mencapai $82,4 \%$ atau terdapat 28 siswa yang tuntas dari 34 siswa yang mengikuti ujian.

Pada siklus II, peneliti lebih mendisiplinkan siswa serta menanyakan kesiapan siswa untuk menerima materi sebelum pembelajaran dimulai, peneliti lebih tenang dalam menyampaikan materi serta berusaha menggunakan bahasa yang mudah dipahami oleh siswa sehingga siswa bisa mendengarkan dengan jelas dan memahami materi yang disampaikan, selalu menekankan batas waktu saat kegiatan kelompok sehingga siswa lebih disiplin dalam memanfaatkan waktu, selalu memberikan kesempatan kepada siswa untuk bertanya, menciptakan suasana keakraban diantara sesama siswa dan kelompok serta selalu memotivasi siswa untuk berani memberi tanggapan sehingga mereka tidak ragu-ragu dan malu untuk bertanya. Dari perbaikanperbaikan inilah sehingga siswa merasa lebih senang dengan model pembelajaran yang diterapkan saat belajar dan akhirnya diperoleh peningkatan hasil belajar pada siklus II.

Penggunaan model pembelajaran MURDER pada penelitian ini seiring dengan penelitian yang telah dilakukan oleh peneliti lainnya. Sebelumnya, pengembangan perangkat pembelajaran matematika dengan metode MURDER bernuansa problem based learning $(P B L)$ materi bangun datar kelas VII . Dari hasil penelitian tersebut, diperoleh bahwa model ini cukup efektif untuk menarik minat siswa dalam mempelajari matematika (Eko Andy Purnomo, 2011). Selain pada mata pelajaran matematika, model pembelajaran MURDER dapat pula digunakan pada mata pelajaran fisika. Ref.[7]

\section{KESIMPULAN}

Berdasarkan hasil analisa data serta pembahasan pada penelitian ini maka dapat disimpulkan bahwa penerapan model pembelajaran kooperatif tipe MURDER dapat meningkatkan hasil belajar fisika siswa kelas VIIIC SMP Negeri 16 Palu. Hal ini dapat dilihat pada peningkatan hasil belajar siswa dari siklus I ke siklus II. Untuk hasil tes siklus I diperoleh nilai ketuntasan belajar klasikal sebesar $61,8 \%$ dan daya serap klasikal 70,0\%. Sedangkan pada siklus II diperoleh nilai ketuntasan klasikal sebesar $79,4 \%$ dan daya serap klasikal $78,6 \%$. Untuk hasil observasi aktivitas siswa dan guru pada siklus I yaitu cukup dan baik, sedangkan siklus II berada pada kategori baik. Wawancara pada siklus I, siswa masih bingung dan belum terlalu paham dengan model pembelajaran kooperatif tipe MURDER dan pada siklus II siswa sudah mengerti dan paham dengan model pembelajaran kooperatif tipe MURDER serta merasa senang dengan model pembelajaran yang diterapkan.

\section{DAFTAR PUSTAKA}

[1] Solihatin. Etin, "Cooperatif Learning Analisis Model Pembelajaran IPS," Jakarta: PT. Bumi Aksara, 2008.

[2] Rusman, "Model - Model Pembelajaran", (Mengembangkan Profesionalisme Guru). Jakarta: PT Raja Grafindo Persada, 2011.

[3] Sulipan, "Model Pembelajaran MURDER," (online),(http://sulipan.wordpress.com/2011/05/16/m odel-pembelajaran-murder/, diakses 20 april 2012). 2011

[4] Munawar. Indra, "Hasil Belajar (Pengertian dan Definisi),".

(online),(http://indramunawar.blogspot.com/2009/06/ hasil-belajar-pengertian-dan-definisi.html diakses 25 februari 2011, diakses 20 april 2012) 2009

[5] Depdiknas. Penelitian Tindakan Kelas. Jakarata: Direktorat Pendidikan Nasional 2004

[6] Tim Penyusun.. Pedoman Penyusunan dan Penilaian Karya IImiah. Palu: FKIP UNTAD. 2005

[7] Purnomo, Andy Eko,. Pengembangan Perangkat Pembelajaran Matematika dengan Metode MURDER Bernuansa Problem Based Learning (PBL) Materi Bangun Datar Kelas VII, (online), http://digilib.unimus.ac.idhttp://digilib.unimus.ac.id, diakses 21 april 2012) 2011 